\title{
EL LENGUAJE DE LA NORMA Y LOS INDIVIDUOS FRÁGILES.
}

\author{
Carlos Skliar ${ }^{1}$ \\ Facultad Latinoamericana de Ciencias Sociales - FLACSO
}

\begin{abstract}
Resumen
En este texto se aborda la cuestión del cuerpo en tanto campo de batalla entre la normalidad y la belleza de un lado, y la singularidad, la soledad y la fragilidad de otro lado. La cuestión reside en comprender cuál es la diferencia entre aquellos cuerpos -y lenguajes- que son hablados en relación a aquellos cuerpos -y lenguajes- que hablan. Quizá no sea ésta una cuestión final, que finaliza, pero nos presenta una complejidad de todas las cuestiones aquí parcialmente formuladas, y vuelve imprescindible una noción de cuerpo completamente distinta. Una noción de cuerpos en relación, donde no exista ningún vestigio acerca de lo que falta o de lo que hace falta. El fin de la idea del cuerpo normal. Huir de la obligación de juzgar. El encuentro con el otro, sin condiciones. La transformación del uno mismo en alteridad. La razón que nos asiste para definir al otro sujeto se ha desvanecido casi por completo, pulverizada en sus argumentos y hecha jirones en su naturalización. Ya no hay sujeto-uno o, para mejor decir, nunca hubo un sujeto auto-centrado, omnisciente, capaz de rellenarse y hacerse absoluto, completo. Es esta la razón a desmitificar. Ser capaces de una teoría de la debilidad, de lo fragmentario, de la vulnerabilidad, de lo incompleto y no ya como condición precaria, de agonía, sino como aquello que nos hace humanos. Con esa intención se aborda la cuestión de la locura, la debilidad mental y la barbarie, a través de un recorrido de textos filosóficos y literarios que, quizá, compongan una posible teoría de la fragilidad.
\end{abstract}

Palabras claves: cuerpo; debilidad; fragilidad; normalidad.

\section{THE LANGUAGE OF THE STANDARD AND FRAGIL INDIVIDUALS.}

\begin{abstract}
This text addresses the question of the body as battleground between normality and beauty, and, on the other hand, uniqueness, loneliness and fragility. The question is to understand what is the difference between those bodies - and languages - that are spoken about and those bodies - and languages - speaking. Maybe this is not a final question, which ends, but one that presents a complexity of all the issues here partially formulated, and is drives essential a completely different notion of body. A notion of bodies in relation, where there is no trace about lacking or what is missing.The end of normal body idea. Escape from the duty to prosecute. The encounter with the other, without conditions. The transformation of the self in otherness.The reason which helps us to define the other subject faded almost completely, sprayed in their arguments and shattered in its naturalization. There is no longer a united subject or, better to say, there has never been a subject self-centered, all-knowing, able to fill up and make itself absolute, complete. This is the reason to demystify. Being capable of a theory of weakness, the fragmentary, the vulnerability of incomplete and no longer as poor condition of agony, but as one that makes us human. With this intention, it is discussed the issue of
\end{abstract}

\footnotetext{
${ }^{1}$ E-mail: skliar@flacso.org.ar
} 
insanity, mental weakness and barbarism, through a pathway of philosophical and literary texts that, perhaps, compose a possible theory of fragility.

Key-words: body; weakness; fragility; normality.

\section{A LiNGUAGEM DA NORMA E OS INDIVÍDUOS FRÁGEIS.}

Resumo

Neste texto se aborda a questão do corpo enquanto campo de batalha entre a normalidade e a beleza de um lado, e a singularidade, a solidão e a fragilidade de outro lado. A questão reside em compreender qual é a diferença entre aqueles corpos - e linguagens - que são falados em relação àqueles corpos - e linguagens - que falam. Talvez não seja esta uma questão final, que finaliza, mas que nos apresenta uma complexidade de todas as questões aqui parcialmente formuladas, e torna imprescindível uma noção de corpo completamente diferente. Uma noção de corpos em relação, onde não exista nenhum vestígio acerca do que falta ou do que faz falta. O fim da ideia do corpo normal. Fugir da obrigação de julgar. O encontro com o outro, sem condições. A transformação do si mesmo em alteridade. A razão que nos assiste para definir ao outro sujeito se desvaneceu quase por completo, pulverizada em seus argumentos e despedaçada em sua naturalização. Já não há sujeito-uno ou, para melhor dizer, nunca houve um sujeito autocentrado, onisciente, capaz de encher-se e fazer-se absoluto, completo. É esta a razão a desmitificar. Ser capazes de uma teoria da debilidade, do fragmentário, da vulnerabilidade, do incompleto e não já como condição precária, de agonia, mas como aquele que nos faz humanos. Com essa intenção se aborda a questão da loucura, a debilidade mental e a barbárie, através de um percurso de textos filosóficos e literários que, talvez, componham uma possível teoria da fragilidade.

Palavras-chave: corpo; debilidade; fragilidade; normalidade. 


\section{Introducción: Cuerpo, perfección y normalidad.}

Sólo el cuerpo sabe o puede o intenta eludir el engorro y la prisión de la normalidad, ese recipiente insulso que propaga su ley hacia las extremidades de la apariencia, al insistir con su única potencia, su singularidad ejemplar: ese emblema -austero, reservado, propio- de una belleza imperfecta frente a la obsesiva pretensión de la perfección impostada.

¿Qué hacer con el cuerpo?: dejarlo allí, donde está, o ir en otra dirección, o darse cuenta que no hay otra cosa que el cuerpo: mirar, soñar, olfatear, acariciar, pensar, amar, escribir, doler, tocar, huir, estar, soñar, leer, jugar, hablar, gesticular, imaginar, narrar: ¿hay algo, por acaso, que se haga fuera del cuerpo, sin el cuerpo, dejando a un lado el cuerpo, prescindiendo del cuerpo, ignorando el cuerpo?

La política, la rabia, la desazón, la tristeza, el olvido, la memoria, el amor, la poesía, el prejuicio, la desnudez, el llanto, nuestra soledad: nada hay, nada es, que no sea una percepción del cuerpo, quitar el cuerpo, poner el cuerpo, entremezclar los cuerpos, mostrar el cuerpo, sentir el cuerpo, jugarse el pellejo, meter la pata, andar con el pie torcido, levantarse con la pierna izquierda, no dar el brazo a torcer, el corazón que se sale por la boca, el alma hecha pedazos, el pecho inflamado, la cabeza erguida, los escalofríos, la cabeza en otra cosa, perder la cabeza, nunca dar la espalda, dar siempre la espalda.

El cuerpo perfecto no sólo es inexistente, sino que además resulta ofensivo, inmoral, impúdico, un híbrido entre las máquinas rectas y la sangre deshilvanada. Como lo ha escrito Jean-Luc Nancy: "Diferentes, los cuerpos son todos algo deformes. Un cuerpo perfectamente formado es un cuerpo molesto, indiscreto en el mundo de los cuerpos, inaceptable. Es un diseño, no un cuerpo" (NANCY, 2007, p.16).

El cuerpo perfecto se mira a sí mismo y no tiene nada para decir a no ser: mírenme. Pero es mejor mirar hacia los cuerpos desencajados, a los que no se sostienen en pie, los que parecen incómodos, desatinados, desaliñados. Mirarlos con buenos ojos, con mirada limpia -como lo expresaba Ángel González en su poema Muerte en el olvido (2008)- o, como decía Nietzsche (1976), con una mirada sin manchas, ni virtuosa ni perezosa, que no juzga sino que acompaña, habilita, da 
paso, sin conmiseración ni simulada agonía.

Habría que apreciar una belleza distinta, diferente de los atributos simétricos, geométricos, y no eludir la conversación con aquellos que más tarde se conocerán con esos nombres que solo los adultos son capaces de inventar para, enseguida, olvidar: los jorobados, los paralíticos, los quemados, los mutilados, los leprosos, los ciegos, los tullidos, los cojos, los tuberculosos, los dementes, los autistas, los deficientes, los incapaces, en fin, los débiles, los frágiles de cuerpo.

Duele la suposición de que un cuerpo pudiese ser abandonado o apartado o removido de su espacio y su tiempo por causa de un equívoco absurdo y anti-ético de la mirada; habría que escuchar las historias de hombres y mujeres y niños y niñas cuya vida hubo de ser interrumpida por la torpeza infinita del recelo ignorante de otros ojos que se pretendían astutos y a salvo.

Sin embargo, no se trata de la historia de los desparejos famosos, de la vida entendida como la superación de una dificultad abismal, de la proeza por vencer con enjundia todo límite, incluso más allá de las fuerzas de este mundo.

La belleza despareja habita en todos los cuerpos, sin privilegios. Es la belleza de este mundo, una excepción sin excepciones, historias comunes donde lo que ofende es, en verdad, el privilegio de lo normal, la extrañeza impúdica y el aparente heroísmo, la sensación de que nadie los dejaría nunca en paz, la incógnita irresoluble por vacía: ¿es posible una existencia sordo-ciega; es posible vivir entre lobos y apartado de los hombres; es posible pasarse 18 años dentro de un pozo en cautiverio; es posible andar en cuatro patas, sin lenguaje; es posible la joroba y las matemáticas; es posible la sordera y la música; la sordera y la pintura; es posible la filosofía, la poesía y la demencia; es posible la escritura y el no-ver; es posible la escultura y la anomalía de las manos? ¿Es acaso posible la existencia de otras vidas, de otros cuerpos, de otras soledades?

\section{Locura, soledad y encierro.}

Juana Castro escribió en el año 2005 un libro de poemas inquietante, titulado Los cuerpos oscuros; por medio de una escritura que intenta nombrar quizá 
la más impronunciable de todas las cosas: la demencia y sus encierros, el encierro y sus demencias.

Uno de los poemas que componen el libro conmueve especialmente, pues deja al lector allí donde nunca quisiera estar: al borde mismo del abismo de lo trágico. El poema se llama Los encerrados ${ }^{2}$ y es en esa brevedad aguda, en esa descripción acuciante y sin respiro, donde se puede leer lo que de otro modo sería imposible siquiera imaginar: la voz del lenguaje de los encerrados, los enclaustrados, los atrancados, los oscurecidos en medio de la luz del día; esos seres a quienes nadie les habla, esos seres que parecen no hablar con nadie.

Las metáforas sobre las demencias y su encierro -lo sombrío, lo infausto, las tinieblas, el silencio, el peligro, el ahogo, el abandono, etcétera- nunca alcanzan y languidecen delante de tanto horror y tanta incapacidad para comprender la radicalidad de lo singular. Y la duda sobreviene: ¿hay allí una voz? ¿Qué dice? ¿A quién se lo dice? ¿Con cuáles palabras? ¿Para decirnos algo? ¿Nos lo dice a nosotros?

Se trata de un lenguaje cuya realidad no puede pensarse apenas como deterioro, pérdida, desvío, patología o desatino. Si así se hiciera, quedaría una sensación apenas de lo literal, discreta y mezquina. Debería decirse: es un lenguaje incomparable, como todo lenguaje.

La cuestión reside en comprender cuál es la diferencia entre aquellos cuerpos -y lenguajes- que son hablados en relación a aquellos cuerpos -y lenguajes- que hablan.

En efecto, hay cuerpos y lenguajes de los cuales se habla y cuerpos y lenguajes que hablan, que toman la palabra, que se arrogan la virtud del decir. Como si el mundo estuviese, en efecto, partido en dos: de un lado, los acallados, los que no tienen nada para decir, ni a quién decirlo; los que no se dirigen a nadie;

\footnotetext{
2 "Los atrancados. Los encerrados vivos. /Oscurecidos, aherrojados en el último cuerpo de la casa, se consumen y hablan / Corre la muerte afuera / Hablan con el televisor y con sus muertos / Olvidan los plazos del futuro igual que olvidan hoy / qué cosas les dolieron ayer tarde / No abren las ventanas porque no entren el sol ni los ladrones / y el cielo está techado de uralita, y no quieren saber a cuántos años / se murieron su madre ni su padre / Por olvidar, olvidan enfadarse, se tragan las horas, el caldo, las pastillas, y arrastran / su nombre y sus dos pies como un misterio / Y leen y releen, una vez y otra vez, tercos como funambulistas / la cuenta de la luz, el testamento / la invitación de boda de una sobrina nieta" (Juana Castro, Los cuerpos oscuros. Poesía Hiperión, 2005: 47).
} 
anónimos que sólo podrían llegar a tomar la palabra y usar su voz sólo para justificar su presencia y para disculpar su existencia. Y luego están los que dicen por sí y por otros, los que cubren el mundo de palabras, explicadores de ocasión que justifican vidas propias y ajenas, que todo lo saben y ocultan con refinada técnica y su lenguaje infecto sus proverbiales ignorancias.

Pero el mundo, a poco que lo escuchemos con atención, no es así.

De hecho acerca del lenguaje de las demencias se ha escrito mucho, pero a partir de un lenguaje especializado con pretensiones de claridad, el lenguaje arrogante que lo explica todo, ese lenguaje compuesto a propósito de la distinción entre lo que debería ser lenguaje y lo que dejaría de serlo. ¿No sería acaso posible que el lenguaje de las demencias pudiese hablar por sí mismo, en sí mismo, desde sí mismo?

También sobre las experiencias de encierro se ha dicho demasiado. Sin embargo, la distinción vuelve a ser necesaria: hay cuerpos encerrados de los que se habla desde una posición de libertad y hay cuerpos encerrados de los que se supone nada podrán pensar al respecto. ¿Acaso no se toma la palabra al interior del propio encierro? ¿La única posibilidad de narrar el encierro es esperando la luz de lo exterior? ¿Siempre la civilización procede de la oscuridad de la caverna y se dirige hacia la claridad del llano?

Esbozo de una idea: se trata, quizá, de un lenguaje y de un cuerpo que no se dirigen a nosotros sino a un vínculo esencial existente en el espacio tenue y lúcido que permanece móvil y frágil entre la memoria y el olvido. Un fragmento del poema Los encerrados dice: "Hablan con el televisor y con sus muertos".

Hablan, tal vez, a partir del movimiento subrepticio de una luz que se escapa, con el fragmento de un recuerdo a medias perdido o partido, con el desplazamiento azaroso de las cosas, con el enigma del misterio, con personas presentes a las que se les otorga otra edad, otros rostros y otros nombres, en territorios de la infancia donde ya nada ni nadie permanece, con detalles bordados en el ángulo más pequeño de la mirada. 
Hablan, quién lo sabe, con una voz cuya moral se ha abandonado o fatigado o ya harta de sí misma, con palabras cuya resonancia no está en el lenguaje sino en el oído, a través de un dolor antiguo que quedó pendiente, con los pies arrastrándose por pasillos sin desembocadura.

Y cuando por acaso hablan con alguien, se dirigen a alguien en particular, solo encuentran a cambio desconcierto, indiferencia, quizá la voluntad efímera de la traducción imposible, el rápido resguardo en la lengua sana, el retiro hacia la normalidad más banal de la que se dispone.

Una de las voces más limpias y testimoniales en este sentido es la de Alda Merini, poeta italiana nacida en 1931, quien atravesó varios períodos de internación, silencio y aislamiento. Uno de sus libros, Clínica del abandono (2008) está compuesto, entre otros poemas, por aquellos que dictó telefónicamente a sus amigos durante los tiempos de encierro en una suerte de manicomio carcelario. De ese libro, este poema, La otra verdad:

En los tiempos de la prisión inútil / yo amé a un compañero mío / un pobrecito sin santidad. / Y así de este amor infeliz / has nacido tú, / flor de mi pensamiento. / Nadie en el manicomio ha dado jamás un beso / si no es al muro que lo oprimía / y esto quiere decir que la santidad / es de todos, / como de todos es el amor (MERINI, 2008, p. 143).

El lenguaje de la demencia dice: tiempos de la prisión inútil; dice: amar en una prisión inútil; dice: amor infeliz que se ama en medio de una prisión inútil; dice: de todos es el amor, es decir, de cualquiera y de cada uno.

¿Desear estar solos es ya un primer esbozo de la locura? Pirandello lo ha escrito de este modo:

Yo quería estar solo de una manera completamente insólita, nueva. Todo lo contrario de lo que pensáis: es decir, sin mí, y al mismo tiempo en un entorno extraño. ¿Os parece ya esto un primer signo de locura? La locura podía ya hablar en mí, no lo niego, pero os ruego que creáis que la única manera de estar verdaderamente solo es esto que os digo (2010, p. 76).

El cuerpo de la poetisa Alda Merini -según una fotografía de la época- está mitad desnudo, mitad abierto; faldas sucias, zapatos raídos y calcinados por andar a través de pasillos de descascaradas pinturas, el torso libre, blanco, como si sus pechos enunciaran las cosas más graves y elementales de la vida: la leche, la nieve, el papel aún sin encender del tabaco, las páginas donde se inscribirán poemas, los 
ojos sin furia, el vestido de novia guardado en un almacén perdido de una remota aldea.

Todo es blanco en Alda, salvo los hombres que se esconden de su mirada y que temen ser despedazados. Sí, en su italiano: “Appena mi guardi e temi di essere sepezzato" ("Apenas me miras y temes ser despezado").

Alda no siente el frío, es decir, no puede ser sino ardorosa la tertulia de sus palabras y la vigilia de la partida. Sin embargo, su cuerpo está caduco de antemano, como si la locura no tuviera contemplación con las mujeres, y azotara con particular ensañamiento la desnudez de las poetisas.

Hacia donde Alda mira no hay otra cosa que el interior de un edificio arrogante que, en su soberbia y sus canceles, pretende separar la verdad de la vanidad, la sensatez de la abundancia, cada hoja sedienta de escritura de todas las convenciones miserables.

La apartaron una y otra vez.

Apartar: ¿de quién es la parte, de quién es la partida? ¿Quién puede excusarse de tanta veleidad absurda, de tanta normalidad que aprieta los dientes hasta morder la lengua y decir lo incomprensible?

Alda se queja que nadie en el manicomio quiera besarla y aspira con avidez la ausencia de vidas ajenas, como si se tragase la hoja del tabaco, lejos de Dios, fuera de toda fácil cordura. El dolor la embiste y la retiene entre su furia. Agotada, siente que se derrumba toda y que llora porque es de arcilla, porque es débil. Alda habla con la desfiguración del tiempo y con el soplo de una vela apagada.

A través de una hendija prepara una fogata alta cada noche de luna para recibir al mundo y transformarlo en lucidez, desnudez y poesía. La fogata, pues, está encendida, aunque nadie viene a su encuentro, aunque nadie llega, aunque nadie sabe de la encarnada y desencarnada sensatez de su espera, en una carretera alejada, muda.

Nadie viene porque ninguno desea la cegadora claridad de una fogata. Quizá porque el fuego en ascenso, durante las noches de luna clara, es el recuerdo más sombrío de todas las cenizas reencendidas: ese recuerdo de locura que, en cada uno, en cada una, no quisiera ser recordado por nadie. 


\section{El cuerpo solitario, sin héroes ni víctimas.}

No es por casualidad sino por padecimiento que Mary Shelley repite con tanta insistencia la palabra "soledad" en su libro Frankestein, el moderno Prometeo. Y tampoco es por acaso que Georg Lichtenberg atravesaba los metros que separaban su casa de la Universidad de Gotinga, sintiendo sobre sus espaldas -allí donde su joroba parecía crecer día a día- la mirada sucia, impiadosa, de los habitantes de Ober-Ramstadt y apuraba el paso, un paso corto, diminuto, hasta sentirse a salvo en sus aulas de física y matemáticas, entre sus estudiantes, que le admiraban incondicionalmente.

En no más de trescientos metros a través de un poblado lleno de supersticiones, palacios de cristales rotos y el deambular de las ratas, Lichtenberg recorría sin desearlo la esfera completa de la mirada humana: la burla, el desprecio, el empequeñecimiento, la sorna, la humillación y la admiración, la pleitesía, la honra, la ingratitud.

Era objeto de comentarios jocosos entre los vecinos debido a su apariencia particular, y padecía el tormento de ser mal mirado, de ser mirado borrosamente, por ojos que por mal ver, eran ojos asesinos. El matemático escribió en uno de sus tantos cuadernos: "Alli donde el ojo ve borrosamente, ya hay una especie de muerte" (LICHTENBERG, 1989, p.58).

¿Cuál era su pecado fisonómico, la culpa corporal con la que debía cargar y soportar el escarnio de la gente? El de ser un hombre bajo, sin llegar al enanismo, debido a una rara enfermedad durante su infancia que atrofió su desarrollo e hizo que su cuerpo quedara reducido a un metro y medio de altura, dejando como secuela una joroba prominente atrás de sí, como una sombra persecutoria, una alteridad indiscreta, que siempre acechaba por encima de los hombros.

Lichtenberg era, al mismo tiempo, de forma indisociable, un hombre enfermo, un brillante matemático y físico, y un escritor deslumbrante. Todo en él podría reducirse a lo mínimo y sustancial: las fórmulas acotadas, sintéticas, de la ciencia, su cuerpo abigarrado y estrecho, y sus aforismos, esa escritura reducida y decisiva como un látigo, como un relámpago.

Pero la metáfora de lo pequeño resulta tan obvia como indignante. 
Tampoco habrá de cometerse el equívoco de la grandeza, esa imagen igualmente torpe del gran hombre aprisionado en un cuerpo pequeño, su enorme sapiencia dentro de un envase reducido, su inmensa escritura de manos pequeñas: "Habría que decir 'soy esto' -escribió-. No se dice 'la redondez está en la esfera'. Es la similitud lo que nos seduce" (LICHTENBERG, 1989, p. 112).

En su rostro, de frente alta, nariz en punta y labios apretados, la expresión satisfecha de una soledad voluntariamente elegida, el punto de la esfera donde reside la patria de los gestos, la patria humana. Porque no es el tamaño de un hombre el que explica su vida, ni es la joroba lo que la justifica, sino ese rostro que guarda en su semblante todas las consecuencias de la existencia: sus enfermedades, su amor por la filosofía y los números, su escritura breve e intensa: "Un rostro no se deja analizar en un instante: necesita una consecuencia" (ibídem: 93).

\section{La insana obsesión por los diferentes.}

Nunca es suficiente el ensañamiento con los débiles, los tontos, los imbéciles, los retrasados: arrojados desde los montes, desheredados, desarropados, abandonados a su propia suerte y muerte, condenados a un ostracismo, prohibidos del libre albedrío, excluidos e incluidos como si se tratase de entidades autómatas, jamás absueltos de sospecha o mala intriga, despojados de sí, angelizados y demonizados.

Nunca es demasiada la sospecha, la injuria, la tontería que impide ver lo humano más allá de un espejo liso, sin marcas, sin dobleces.

A la desdicha generalizada de normalidad se les añade otra desdicha aún mayor: no se les deja elegir su propia nostalgia, su propia melancolía, ni su propia carcajada. Se los ve inútiles, incluso, para la recta esclavitud, la servidumbre dócil, abandonándolos a la pala y el pico, a la fabricación de objetos repetidos, a la alfabetización siempre inicial, a la insana postergación de la igualdad.

Los débiles, los tontos, los imbéciles, los retrasados -si algo así existiera, si algo así pudiera portar esos nombres- son metáforas de un mundo estrecho, absurdo y apurado. Muestran las brechas, los orificios, por donde el mundo de la soberbia y la jactancia se derraman y se perforan de hipocresía y espanto. 
Metáforas erráticas de la vida falsa, imágenes despintadas de una vida falseada: nuestra ignorancia es de tal magnitud que de verdad creemos verlos en su oscura existencia; nuestra torpeza es de tal autoritarismo que de verdad creemos vernos en nuestra limpia existencia.

"Ya no se nombra de este modo a esas personas", se dice por ahí.

Y el lenguaje, exhausto, responde que es así como todavía se los siente y piensa. Aún en aquellas historias donde la inteligencia no juega papel alguno, la culpa de los débiles, los tontos, los imbéciles, los retrasados, es evidente o se hace evidencia.

La culpa, sí, de la fragilidad, de los seres frágiles.

Por ejemplo la que es posible leer en la novela de Philip Roth Némesis (2010) cuya historia transcurre en el verano de 1944, en la ciudad americana de Newark, cuando una espantosa epidemia de poliomielitis va dejando su funesta huella entre niños y jóvenes.

Lo que parece ser una enfermedad lejana y ajena, comienza a sentirse próxima y propia. Nadie, ni siquiera los afamados médicos saben de dónde viene o cómo se esparce: ¿será la comida, los escupitajos de los italianos, la inmundicia de los basurales, el ardor inclemente del verano? ¿Vendrá de la ciudad más cercana, o serán los judíos, o estará en medio del sudor de los juegos en los patios de las escuelas?

Némesis es una novela de lenguaje seco y abatido, cuyo protagonista es un maestro obligado a deambular entre las despedidas a los alumnos muertos, la compasión infinita hacia sus padres, el cuidado de aquellos que aún no enfermaron y la necesidad de sostener con su palabra ese tenue equilibrio entre las sospechas generalizadas, la culpabilización a granel, y el derroche del egoísmo.

Durante ese verano asfixiante y sepulcral se tuerce el rumbo de la pregunta que todos allí pronuncian sin tregua. Ya no se trata de: ¿qué causa la polio?, sino más bien: ¿cómo es que se propaga?

En el pueblo vive Horace, un retrasado mental que suele vagar sin sentido por las calles y que, en ocasiones, pasa por la escuela a ver a los niños jugar, sin 
otra intención que la de quedarse quieto en un canto y, de ser posible, estrecharles las manos. En apariencia Horace no comprende nada: no comprende qué es el mediodía, qué es el calor, qué la sombra, qué la enfermedad. Así lo describe Roth:

\begin{abstract}
Pasaba Horace de nuevo, sin duda en dirección al centro, sin comprender que era sábado y que, en verano, las instalaciones cerraban el sábado a mediodía. No estaba claro que comprendiera también lo que significaban "verano", "centro", "cerrado", o "mediodía", de la misma manera que el hecho de que no caminara por el lado en sombra de la calle probablemente significaba que era incapaz de elaborar un pensamiento rudimentario para conceptualizar "sombra" o siquiera buscarla por instinto, como haría un perro en semejante día (ROTH, 2010, p. 50).
\end{abstract}

Todo el mundo allí está extenuado e histérico, agotado y en tensa vigilia por la fiereza de la calamidad. El encierro se hace cada día más agobiante y sólo algunos, los más pequeños, salen a las calles para asistir a la colonia de verano. Todos están a flor de piel y con la sospecha en la punta de la lengua, como si se tratara de un arma de fuego dispuesta al gatillo en el centro de la palabra.

En poco tiempo la pregunta vuelve a mutar. Ya no se trata de saber ni qué causa la polio, ni cómo se propaga, sino quién tiene la culpa de la epidemia.

¿Cómo no acusar, entonces, a Horace, alguien que no conoce el sentido de las palabras, que expone su cuerpo sin conciencia al calor demencial del mediodía y que ni siquiera tiene los instintos de un perro? ¿Qué réprobo mejor que un débil para atribuirle la culpa de haber transmitido la polio por el pueblo? ¿Quién sino Horace, incapaz de defensa, incapaz de lenguaje, incapaz de todo, puede ser el más perfecto de los culpables? Dice un joven estudiante:

Él la está extendiendo [...] Estoy seguro. No debería haber perdido los
estribos, sé que ese hombre es un retrasado, pero no está limpio y
propaga la enfermedad. Va de un lado a otro, la baba le cae aquí y allá,
estrecha la mano de todo el mundo, y así es como dispersa los gérmenes
por todas partes (ROTH, 2010, p. 95).

Es Horace quien propaga la epidemia, dice un joven. Y está convencido de ello: su debilidad y su suciedad son, a su entender, características comunes presentes en los débiles; es el débil quien va de aquí para allá estrechando las manos de la gente y dispersando los gérmenes por todas partes. El maestro intenta desestimar esa acusación y convencer al joven de que nadie sabe cómo se propaga la poliomielitis. Pero las cartas están echadas: nadie logrará quitar las sombras que se yerguen sobre Horace, nadie quiere pensar mejor o de otro modo, todos desean 
que haya un culpable, todos buscan en el indefenso la razón del mal.

Éste es el culpable: el que no sabe, el que no se da cuenta, el que es inconsciente de esos actos que provocan más y más tragedia, el sucio, el retrasado, el imbécil, el incapaz. Y cuando la sospecha recae sobre el frágil, la culpa es aún más perfecta, más incontrastable, más rotunda aún. Una culpa anudada a un lenguaje falaz -acusador, instigador, nervioso, deshonesto- que nadie contestará y que, enseguida, se propagará junto a la epidemia de polio. Y más allá todavía. Más lejos. Durante más tiempo. Sin cura. Sin remedio.

\section{La aniquilación del nombre propio.}

Los nombres que atribuimos a otros nunca se dirigen a los otros. Los damos, pero no se los damos. No los ofrecemos: los instalamos como signos debidos en una realidad indebida. Son nombres que nombran a los demás pero que no los llaman. No los convocan a venir, sino a quedarse quietos, a permanecer inertes. Ningún nombre ha cambiado radicalmente una relación. Son términos para usar entre pares y para volver a separar, una y otra vez, a los supuestos impares.

Esos nombres se usan con vehemencia pero nadie se ensucia las manos ni se entierra los pies. Describen lo que sería el otro, si acaso el otro estuviese quieto, aquietado, ajustado a unos ojos que se pertrechan detrás de la apariencia civilizatoria de una idea: ¿Cómo nombrarlos sin sus nombres? ¿Qué nombres darles si sus nombres ya le fueron dados y son ésos, ésos mismos, los suyos? ¿Cómo llamarlos si es que no están próximos y sin aproximarnos?

Vuelve a nosotros, a este tiempo, como una serpiente enroscada aquella última imagen de esos cinco prisioneros de Auschwitz, en un blanco y negro terroríficos, con unos atuendos harapientos que desbordan sus cuerpos extenuados, casi exánimes.

Podría tratarse de cinco personas cualesquiera, pero no lo son. Hay instantes de la vida humana, de la historia de la vida humana, en que ninguno, nadie, merece ser cualquiera. Esas cinco personas, son cinco prisioneros con alguna discapacidad, que están con el cuerpo inclinado hacia la última fragilidad, 
desvencijados como trastos viejos, aturdidos por las medicinas y los experimentos, que ven y no ven la cámara disparadora de imágenes.

La soledad como una cámara de gas.

Con sus pijamas rayados, mezcla de campo de concentración y de hospicio, toman una pose desconcertante, inquieta, desesperada, apoyándose unos en otros, como si ya nadie pudiese sostenerse en pie por sí mismo y dependiesen de un único y último apoyo, de un sostén de jirones y fragmentos rotos.

Sus rostros están casi fuera del cuerpo, desorbitados, desencajados, y sus ojos parecen descompuestos de tanto padecer.

La soledad como sucio experimento.

¿Por cuáles sucios laboratorios habrán pasado? ¿Qué nombres tenían, de dónde eran, qué vida llevaban hasta el momento en que les fue tomada esta imagen? ¿De qué se les acusaba? ¿Y cuánto tiempo, cuántos segundos faltarán para que sean asesinados, enterrados, agolpados sobre otros deshechos?

Sabemos que antes de los campos de concentración miles de cuerpos defectuosos fueron asesinados sin contemplación al interior de la soledad atroz de los asilos. Hacia el año 1945, 750 mil individuos con algún defecto, visible o invisible, ostensible o austero, en los pies o en el rostro, en los ojos o en los oídos, fueron eliminaos por el régimen nazi.

La soledad que no deja en paz. La soledad como indefensión.

Y es que nunca se los ha dejado en paz, y habrá que sublevarse contra aquellos que esgrimen la sencilla e imbécil razón según la cual hay quienes están vivos pero no deberían haber nacido nunca, y hay quienes han nacido pero deberían estar muertos.

¿Qué viene después de la aniquilación, qué hay después de identificar un cierto tipo de cuerpos que enseguida, más tarde o más temprano, serán condenados a distintas muertes -la muerte común, la muerte del experimento, la muerte del exterminio, la muerte de la disgregación, la muerte del exilio, la muerte de su soledad-? ¿Cómo sería posible plantearse siquiera una conversación cuando la soledad, así, es como un disparo en la nuca? 
Aquello que nos era dado a saber hace un tiempo era que la normalidad se revestía con la imagen de un dios absoluto, incontestable, tiránico. Todas nuestras miradas se concentraban en sospechar de los demás. Y nosotros, bien a salvo: profesionales cuya tarea era la de corregir, identificar las ausencias, ser impiadosos con los desvíos, perseguidores de deformidades, hablantes en oídos sordos, inteligentes frente a los débiles, evaluadores eficaces. La deficiencia -así nombrada- no era más que un dato periférico que confirmaba la norma. Y la norma se erigía como centro de gravedad, como un imán hacia el cual tendían todas nuestras buenas y nobles acciones.

Pero antes de ser profesionales algo nos tuvo que haber pasado. Fuimos alumnos, en cierto sentido también nos miraron con sospecha y, a veces, con desprecio, humillación. Hay otra historia aun: la del miedo o el recelo o la ignorancia o el desprecio por aquellos seres extravagantes y ajenos que formaban parte de nuestras aulas o de nuestras calles o de nuestras familias. Lo humano como la supresión de lo humano, lo humano como una idea mezquina de lo humano, lo humano como aquello que no admite excepcionalidad, singularidad, irreverencia, desatino.

Hace falta volver a pensar nuestra relación con aquello que difiere de lo que creemos ser nosotros mismos. Hace falta no solo el sinceramiento, la transparencia o la constricción. Hace falta algo más. Un gesto tal vez desmesurado. No sólo un cambio de narrativas o de biografías o una reescritura prolija que corrija el sinsentido anterior. Una ética y una política de la debilidad. La vulnerabilidad propia como el escenario de nuestra sensibilidad y nuestro pensamiento. La autonomía que, también, quiere decir dejar en paz. No abandonar: dejar en paz.

Es una experiencia de la fragilidad porque se trata de un saber en el cuerpo. La insurrección de los conceptos frente a la complacencia indiferente. No ser impunes cuando hablamos del otro, no ser inmunes cuando el otro nos habla.

La ingenuidad es tan peligrosa como la obsesión. El territorio de la diferencia se encuentra devastado por las sucesivas cruzadas que intentaron acabar con la alteridad. Aún hoy la cultura, lo social y sus instituciones, atraviesan 
por campos minados: recambios de nombres, cantos de sirena integracionistas, la supremacía en extremo de un lenguaje jurídico, el reposicionamiento de la idea de lo normal, la belleza anoréxica y digitalizada de los cuerpos contemporáneos, no hacen más que ofrecernos un espejo deformado, un espejo que no devuelve la imagen despareja de lo humano sino que produce otra imagen a semejanza de la normalidad. ¿Es cuestión de un miedo milenario, de un misterioso y siempre astuto concepto de belleza, de la incapacidad suprema por hacer más extenso, siempre, el alcance de lo humano?

Lo que emerge hoy es, por lo menos, ambiguo. La travesía que consiste en desandar las propias huellas, el arraigo de lo normal como lo natural, la confusión entre exclusión e inclusión y la presión nefasta que ejercen los cuerpos publicitarios, no nos dejan en paz. No los dejan en paz. Parece ser que la civilización se tranquiliza al reconocer, a suficiente distancia, la existencia de la diferencia. Pero lo hace de un modo agazapado, reticente, de forma jurídica aunque no éticamente. El lenguaje de los derechos ha alcanzado su máxima aspiración y expresión. Sin embargo, sabemos que un cierto tipo de subversión y radicalidad se vuelven necesarios. Ya no se trata de un nuevo modelo de discapacidad, ni de una nueva organización escolar, ni de novedosas arquitecturas, ni de las conocidas políticas de identidad: la cuestión a indagar es el sí mismo, el problema es el nosotros mismos, cada vez que lo igual, lo común, lo normal son pronunciados como origen y centro del universo.

La razón que nos asiste para definir al otro sujeto se ha desvanecido casi por completo, pulverizada en sus argumentos y hecha jirones en su naturalización. Ya no hay sujeto-uno o, para mejor decir, nunca hubo un sujeto auto-centrado, omnisciente, capaz de rellenarse y hacerse absoluto, completo. Es esta la razón a desmitificar. Ser capaces de una teoría de la debilidad, de lo fragmentario, de la vulnerabilidad, de lo incompleto y no ya como condición precaria, de agonía, sino como aquello que nos hace humanos. No caer en la trampa que nos tienden las angostas éticas hechas a medida del uno y que sólo nos proponen resguardarnos de los demás apenas aceptándolos, respetándolos, tolerándolos. 
En esos espacios, en esos territorios y relaciones está el cuerpo, la centralidad del cuerpo, el ser un cuerpo y no sólo tenerlo. La historia de la discapacidad es, también, una historia de mutilaciones, cercenamientos, distancias extremas y desapariciones de cuerpos: cuerpos cojos, cuerpos sordos, cuerpos ciegos, cuerpos frágiles, cuerpos monstruosos, cuerpos femeninos, cuerpos pobres, cuerpos niños, cuerpos dementes, etcétera.

En diferentes tiempos y espacios ciertos cuerpos -y no otros- fueron sospechados de anomalía y juzgados y condenados sin más. Nadie los esperaba y al tenerlos de frente no hubo más que la acostumbrada tensión de lo normal:

Tensión entre dos aguas, entre lo que está vivo y no debería haber nacido, entre lo que ha nacido y debería haber muerto. En estas circunstancias es fácil, pues, entender que no hay un lugar social esperándolos. Terminan ocupando un no-lugar, exiliados en dicho umbral. A menudo la muerte y la eliminación se personifican en la misma gestación. Son objetos, que no sujetos, marcados por la muerte (BALAGUER, 2004, p.73).

\section{Los bárbaros y una débil teoría de la fragilidad de los cuerpos.}

Quizá no sea ésta una única respuesta ante la complejidad de todas las cuestiones aquí parcialmente formuladas, pero se vuelve imprescindible una noción de cuerpo completamente distinta. Una noción de cuerpos en relación, donde no exista ningún vestigio acerca de lo que falta o de lo que hace falta. El fin de la idea del cuerpo normal. Huir de la obligación de juzgar. El encuentro con el otro, sin condiciones. La transformación del uno mismo en alteridad.

Por ejemplo en la novela Esperando a los bárbaros, Coetzee (2007) retrata un período de la vida de un juez anciano que reside en el juzgado de una pequeña ciudad amurallada. Más allá de los muros del poblado, hay un largo desierto donde se dice que habitan los bárbaros. Todo en el pueblo está organizado y previsto en relación con esa amenaza: las casas protegidas con rejas, la cárcel del juzgado preparada para futuras y masivas reclusiones, los policías entrenados para resistir la invasión, las salas de tortura limpias, todo en medio de una tensión extrema y una constante militarización de la vida cotidiana. 
Los bárbaros no han sido vistos jamás, pero se cuenta de ellos desde hace siglos: se habla de su peligro, de su amenaza, de las barbaridades que cometen a diario. El mito de la existencia de los bárbaros ha pasado de generación en generación y el miedo es aquello que hace respirar a una ciudad que cierra su alma cuando cae el sol. La idea de la presencia de los bárbaros impide, por un lado, una vida normal pero, por otro lado, la habilita en la materialidad y existencia del conjunto de instituciones de estado.

Por culpa de los bárbaros el día es sólo la planificación de la defensa de lo propio, la tarde se asfixia demasiado temprano y la noche se vuelve un reino de tinieblas, miedo y tensa espera, la inminencia de una invasión, la pesadilla constante de los niños:

Los bárbaros salen de noche. Antes de que oscurezca hay que recoger la última cabra, atrancar las puertas y apostar un centinela en cada atalaya para dar las horas. Dicen que los bárbaros merodean por los alrededores durante toda la noche, resueltos a asesinar y saquear. Los niños ven en sueños cómo se abren las contraventanas y cómo los rostros feroces de los bárbaros les dirigen miradas aviesas. "¡Han llegado los bárbaros!", gritan los niños, y no hay quien los tranquilice (COETZEE, 2007, p. 178).

Pero: ¿existirán los bárbaros, de verdad? Nadie osa preguntárselo en el pueblo, nadie se atreve a semejante duda. Quizá de tanto repetir su existencia, parece que sí, que están y que son. Que no solamente se trata de una apariencia fantasmagórica, sino de una existencia cargada de relatos detallados y certeros: los bárbaros son merodeadores, asesinos, violadores, saqueadores, feroces, inhumanos de mirada aviesa y desencajada.

La novela de John Maxwell Coetzee deja abierta la sospecha, el misterio, la tensión. Quizá los bárbaros no existan y no hayan existido nunca. Tal vez se trate solo de un relato de exterioridad para justificar la propia interioridad. Pero el mito, la ficción y, sobre todo, la ley, ya se han convertido en pura cotidianeidad. Y habrá que sostener ese relato y esa vida desde las instituciones hasta las últimas consecuencias.

Lo cierto es que la novela no trata sobre los bárbaros, sino sobre aquellos que esperan a los bárbaros, lo que es muy diferente. Lo que se dice no es sobre los bárbaros, sino sobre el creciente dolor de la existencia durante la interminable y 
agónica espera del supuesto enemigo, como lo expresa el personaje del juez: " $E l$ dolor es la verdad, todo lo demás está sujeto a duda" (COETZEE, 2007, p. 15).

Por ahora pareciera ser que la única solución que se plantea frente al dolor es la exacerbación del lenguaje jurídico: la ley que nunca logra ordenar lo confuso, lo ambiguo, la amenaza. Esa insistente jerga que deja aún más débiles a los cuerpos frágiles, más frágiles a los cuerpos débiles.

\section{Referencias bibliográficas}

BALAGUER, A. (2014). Herencias y actualidad de la discapacidad. Una apertura pedagógica a lo sensible. Barcelona: Editorial UOC.

CASTRO, J. (2005). Los cuerpos oscuros. Madrid: Hiperión.

COETZEE, J. M. (2007). Esperando a los bárbaros. México: Random House Mondadori.

GONZÁLEZ, A. (2008). Nada grave. Madrid: Visor.

LICHTENBERG, G. (1989). Aforismos. México: Fondo de Cultura Económica.

MERINI, A. (2008). Clínica del abandono. Buenos Aires: Bajo la Luna.

NANCY, J-L. (2007). 58 indicios sobre el cuerpo. Buenos Aires: Ediciones La Cebra.

NIETZSCHE, F. (1976). Más allá del bien y del mal. Madrid: Alianza Editorial.

PIRANDELLO, L. (2010). Uno, ninguno y cien mil. Barcelona: Acantilado.

ROTH, P. (2010). Némesis. Barcelona: Literatura Mondadori.

SHELLEY, M. (2006). Frankestein o el moderno Prometeo. Barcelona: Mondadori.

Recibido en: 25.05.2016

Aprobado en: 31.05.2016 